\title{
Assessing the Microbiological Safety Parameters of Minas Artisanal Cheese Samples in Retail Environments in São Paulo, Brazil
}

\author{
Josisleine Recalde Allaion, Karina Ghougassian Barrionuevo and Bernadette Dora Gombossy de Melo Franco *
}

Citation: Allaion, J.R.; Barrionuevo, K.G.; Franco, B.D.G.d.M. Assessing the Microbiological Safety Parameters of Minas Artisanal Cheese Samples in Retail Environments in São Paulo, Brazil. Appl. Sci. 2021, 11, 9331. https://doi.org/10.3390/ app11199331

Academic Editor: Athina S. Tzora

Received: 28 August 2021

Accepted: 30 September 2021

Published: 8 October 2021

Publisher's Note: MDPI stays neutral with regard to jurisdictional claims in published maps and institutional affiliations.

Copyright: (c) 2021 by the authors. Licensee MDPI, Basel, Switzerland. This article is an open access article distributed under the terms and conditions of the Creative Commons Attribution (CC BY) license (https:// creativecommons.org/licenses/by/ $4.0 /)$.
Food Research Center, Department of Food and Experimental Nutrition, Faculty of Pharmaceutical Sciences, University of Sao Paulo, Sao Paulo 05508-000, Brazil; josirecalde@alumni.usp.br (J.R.A.);

karinagbarrionuevo@gmail.com (K.G.B.)

* Correspondence: bfranco@usp.br

\begin{abstract}
Minas artisanal cheese is the best known and most consumed type of cheese in Brazil. Prepared with raw bovine milk and starter cultures, these cheeses face many opportunities for post-processing contamination during their transport to commercial establishments as well as in how they are stored, displayed, and maintained for cutting/slicing at retail establishments. It is a common practice for retailers to purchase entire cheeses from the producers, cut them into smaller pieces for retail sale, and store them at room temperature instead of properly refrigerating them. This study evaluated the microbiological safety parameters of samples of Minas artisanal cheeses collected at retail establishments in the city of São Paulo, Brazil, to more realistically assess consumer exposure to the most common pathogens. Samples were submitted for investigation of Salmonella spp., Listeria monocytogenes, and the counts of total coliforms, Escherichia coli, and coagulase-positive enterotoxigenic staphylococci using culture and real-time PCR methods. A worrisome number of samples failed to comply with the current Brazilian legislation for foods in retail environments and presented more than one non-compliance issue. Results highlighted that quality and safety management tools, such as good hygiene practices and HACCP, in retail environments deserve more attention to reduce the possible risks to consumer health.
\end{abstract}

Keywords: Minas artisanal cheese; safety; quality; hygiene; microbiology

\section{Introduction}

Cheeses are very popular dairy products. Most cheese-making has evolved over the past 100 years from traditional and art-based processes to recent scientific- and technologicalbased processes [1]. Almost every country in the world produces cheeses, and varieties are characterized by their peculiar chemical and sensory properties that vary according to the production process [2]. In Brazil, the state of Minas Gerais is the largest cheese producer and is known for a great variety of cheeses, such as the traditional Minas artisanal cheese that is made from raw cows' milk and endogenous starter cultures $[3,4]$. The production of this type of cheese moves BRL 370 million (approximately USD 70 million) annually, corresponding to 35 thousand tons produced every year. Minas artisanal cheeses are produced using techniques that have been passed from generation to generation in various regions of Minas Gerais, such as Araxá, Campo das Vertentes, Cerrado, Serra da Canastra, Serra do Salitre, Serro, and Triângulo Mineiro [3-5]. The manufacturing process follows the tradition brought to Brazil by Portuguese settlers in the 18th century. These cheeses differ regionally, mainly in the curd pressing phase: in Serro, the curd is pressed with bare hands, while in Canastra, Serra do Salitre, and Cerrado, a cheese cloth is used for the pressing phase and the maturation time chosen by each producer. Thus, artisanal cheeses from Minas Gerais can have different textures and flavors, depending on the composition of the initial culture, raw materials used, and ripening conditions [3-5]. 
The manufacturing process of Minas artisanal cheese is recognized as part of Brazil's historical heritage by The National Historic and Artistic Heritage Institute (Instituto do Patrimonio Histórico e Artístico Nacional (IPHAN). The commercial value of these cheeses has skyrocketed in the last few years due to winning international awards in 2017 and 2018, including gold medals in 2021 at Le Mondial du Fromage et des Produits Laitiers, a cheese and dairy exhibition and festival held in France [3].

Despite the wide recognition given to Minas artisanal cheeses, there are still some concerns regarding commercialization throughout the country [5,6]. Such concerns occur because cheeses prepared with raw milk have been associated with outbreaks of foodborne diseases in several countries, and the occurrence of pathogenic bacteria such as Listeria monocytogenes, Salmonella spp., and enterotoxigenic Staphylococcus aureus in cheeses prepared with raw milk have been frequently reported [4,7-18].

Brazilian agricultural agencies, like other regulatory bodies around the world, have established guidelines and laws for cheese production $[19,20]$. However, Brazilian legislation differ in requirements for production versus retail, generating misunderstandings within the sector. These regulations are not well accepted by artisanal cheese producers as they consider them excessively rigorous for artisanal products [3,5]. Thus, it is not surprising that artisanal cheeses marketed throughout the country are at odds with the requirements of the legislation, both in terms of hygiene and possible risks to consumer health.

Recent studies evidenced the complexity of the microbiota of Minas artisanal cheeses [21-24]. These evaluations were performed with samples collected directly from the producers at their production farms. However, there are many opportunities for post-processing contamination of cheeses in retail stores, during transport to commercial establishments, and in how they are stored, displayed, and maintained for cutting/slicing in these locations $[25,26]$. Usually, retailers purchase whole cheeses from the producers and then cut them into smaller units for retail sale. It is common practice for the cheese to be kept at room temperature instead of being properly refrigerated.

The objective of the present study is to provide data on the hygienic conditions and microbiological safety of Minas artisanal cheese samples collected at retail establishments in the city of São Paulo. We investigate the occurrence of Listeria monocytogenes, Salmonella spp., and the counts of coagulase-positive enterotoxigenic staphylococci, Escherichia coli, and total coliforms using both plating and molecular techniques.

\section{Materials and Methods}

\subsection{Sampling and Bacterial Isolation}

One hundred samples of Minas artisanal cheese were collected at 20 randomly selected retail stores in the city of São Paulo, SP, Brazil, simulating the purchase by a common consumer. The samples corresponded to pieces of cheese from different producers or from different batches from the same producer, as identified on the labels. Producers were located in Serra da Canastra $(n=54)$, Araxá $(n=13)$, Serro $(n=9)$, Cerrado Mineiro $(n=6)$, Pato de Minas $(n=6)$, Salitre $(n=3)$, Triangulo Mineiro $(n=2)$, Campo das Vertentes $(n=2)$, Alagoa $(n=2)$, Coromandel $(n=2)$, and Mendel Pimentel $(n=1)$ in Minas Gerais, Brazil. The samples were numbered A1 to A100, transported to the Food Microbiology Laboratory at the University of São Paulo, SP, Brazil, in containers with recyclable ice and kept refrigerated at $8{ }^{\circ} \mathrm{C}$ until being submitted to testing within a maximum of $24 \mathrm{~h}$ after collection.

\subsection{Sample Preparation for Analysis}

The analytical units for microbiological analysis $(25.0 \pm 0.2 \mathrm{~g})$ were prepared according to IN 62/2003 [27]. The analytical units consisted of $25 \pm 0.2 \mathrm{~g}$, being $12.5 \pm 0.1 \mathrm{~g}$ from the external part and $12.5 \pm 0.1 \mathrm{~g}$ from the internal part of each sample. 


\subsection{Detection of Salmonella spp. and Listeria monocytogenes by Culture Methods}

The analytical units were subjected to the analytical methods described in ISO 6579:1 [28] for Salmonella spp. and ISO 11290:1 [29] for Listeria monocytogenes. Typical Salmonella spp. colonies on XLD and HE agar plates (Merck, Darmstadt, Germany) were subjected to serological agglutination reactions with polyvalent serum (Probac Ltda., Sao Paulo, Brazil), following the manufacturer's instructions. Typical colonies of Listeria monocytogenes on ALOA and OXA plates (Merck, Darmstadt, Germany) were transferred to TSA agar plates, incubated at $37^{\circ} \mathrm{C}$ for $24 \pm 2 \mathrm{~h}$, and subjected to xylose and rhamnose fermentation tests and hemolysis testing on blood agar.

\subsection{Detection of Salmonella spp. and Listeria monocytogenes by PCR Applied to the Pre-Enrichment Broths}

The pre-enrichment broths prepared for detection of Salmonella spp. and Listeria monocytogenes (item 2.3) were submitted to DNA extraction using Quick-DNA ${ }^{\mathrm{TM}}$ kit (Zymo Research, CA, USA). PCR reactions for Salmonella spp and Listeria monocytogenes were performed using the mericon $®$ Salmonella spp and Listeria monocytogenes Pathogen Detection kits (QIAGEN, Hilden, Germany) and a 7500 Real-Time PCR System (Applied Biosystems, Singapore). The tests and interpretation of results followed the instructions of the kits manufacturer.

\subsection{Enumeration and Identification of Coagulase-Positive Enterotoxigenic Staphylococci}

Each analytical unit of cheese was homogenized with $225 \mathrm{~mL}$ of $0.1 \%$ peptone water in a Smasher (BioMérieux, Marcy-l'Etoile, France), and the homogenates were subjected to serial decimal dilutions in $0.1 \%$ peptone water up to $10^{-5}$. From each dilution, $1 \mathrm{~mL}$ was transferred to STX Petrifilm ${ }^{\circledR}$ plates (3M, Sumaré, Brazil) and incubated at $37^{\circ} \mathrm{C} \pm 1{ }^{\circ} \mathrm{C}$ for $24 \pm 2 \mathrm{~h}$, and then the red-violet colonies were counted. The Petrifilm ${ }^{\mathrm{TM}}$ Staph Express Disk was used whenever colonies other than red-violet were also present, followed by incubation at $37^{\circ} \mathrm{C} \pm 2{ }^{\circ} \mathrm{C}$ for an additional $1-3 \mathrm{~h}$. Colonies surrounded by a pink zone were considered positive and included in the counts. Five colonies were selected from each STX plate and subjected to the coagulase reaction according to Bennett and Lancette [30]. Based on the results, the counts of coagulase-positive staphylococci in the cheese samples were calculated. The results were expressed as $\mathrm{CFU} / \mathrm{g}$.

For identification of the species of the coagulase-positive staphylococci isolates, total DNA was extracted with the GenElute ${ }^{\mathrm{TM}}$ extraction kit (Merck, Darmstadt, Germany) and submitted to $16 \mathrm{~S}$ rDNA sequencing at the Human Genome and Stem Cell Research Center at the University of São Paulo, Brazil. The sequences were analyzed with the BLAST algorithm (National Centre for Biotechnology Information, USA)

The enterotoxigenicity of the coagulase-positive isolates obtained from the cheeses was evaluated by investigating the presence of the genes sea, seb, sec, sed, see, seg, seh, sei and sej by PCR, using the primers listed in Table 1.

Table 1. Primers used in the investigation of enterotoxin genes in coagulase-positive staphylococci.

\begin{tabular}{|c|c|c|c|c|}
\hline Gene & Primers & Sequences & Amplicon (pb) & Ref \\
\hline sea & $\begin{array}{l}\text { SEA-1 } \\
\text { SEA-2 }\end{array}$ & $\begin{array}{l}\text { GAAAAAAGTCTGAATTGCAGGGAACA } \\
\text { CAAATAAATCGTAATTAACCGAAGGTTC }\end{array}$ & 560 & [14] \\
\hline seb & $\begin{array}{l}\text { SEB-1 } \\
\text { SEB-2 }\end{array}$ & $\begin{array}{l}\text { ACACCCAACGTTTTAGCAGAGAGTCA } \\
\text { TCCTGTGCAGGCATCATGTCA }\end{array}$ & 633 & [31] \\
\hline $\mathrm{sec}$ & $\begin{array}{l}\text { SEC-1 } \\
\text { SEC-2 }\end{array}$ & $\begin{array}{l}\text { GTAAAGTTACAGGTGGCAAAACTTG } \\
\text { CATATCATACCAAAAAGTATTGCCGT }\end{array}$ & 297 & [14] \\
\hline sed & $\begin{array}{l}\text { SED-1 } \\
\text { SED-2 }\end{array}$ & $\begin{array}{l}\text { GTGGTGAAATAGATAGGACTGC } \\
\text { ATATGAAGGTGCTCTGTGG }\end{array}$ & 384 & [32] \\
\hline see & $\begin{array}{l}\text { SEE-1 } \\
\text { SEE-2 }\end{array}$ & $\begin{array}{c}\text { CAAAGAAATGCTTTAAGCAATCTTAGGC } \\
\text { CACCTTACCGCCAAAGCTG }\end{array}$ & 482 & [14] \\
\hline
\end{tabular}


Table 1. Cont.

\begin{tabular}{lcccc}
\hline Gene & Primers & Sequences & Amplicon $\mathbf{( p b )}$ & Ref \\
\hline \multirow{2}{*}{$s e g$} & $\begin{array}{l}\text { SEG-1 } \\
\text { SEG-2 }\end{array}$ & $\begin{array}{r}\text { AATTATGTGAATGCTCAACCCGATC } \\
\text { AAACTTATATGGAACAAAAGGTACTAGTC }\end{array}$ & 642 & {$[33]$} \\
\hline \multirow{2}{*}{ seh } & $\begin{array}{l}\text { SEH-1 } \\
\text { SEH-2 }\end{array}$ & $\begin{array}{r}\text { CAATCACATCATATGCGAAAGCAG } \\
\text { CATCTACCCAAACATTAGCACC }\end{array}$ & 376 & {$[33]$} \\
\hline \multirow{2}{*}{ sej } & SEI-1 & $\begin{array}{r}\text { CTCAAGGTGATATTGGTGTAGG } \\
\text { AAAAAACTTACAGGGAGTCCATCTC }\end{array}$ & 576 & [14] \\
\hline
\end{tabular}

\subsection{Enumeration of Total Coliforms and Escherichia coli}

The homogenates and serial decimal dilutions prepared as described in item 2.5 were plated $(1 \mathrm{~mL})$ on EC Petrifilm ${ }^{\circledR}$ plates $\left(3 \mathrm{M}\right.$, Sumaré, Brazil) and incubated at $35^{\circ} \mathrm{C} \pm 1{ }^{\circ} \mathrm{C}$ for $24 \pm 2 \mathrm{~h}$. Red and blue colonies with gas were enumer-ated, obtaining the counts of total coliforms $/ \mathrm{g}$. The EC plates were re-incubated at $35^{\circ} \mathrm{C} \pm 1{ }^{\circ} \mathrm{C}$ for an additional $24 \pm 2 \mathrm{~h}$, and the colonies with a bluish color and gas were counted as E. coli/g. Both results were expressed as CFU/g.

\section{Results}

3.1. Salmonella spp. and Listeria monocytogenes

The use of the ISO methodologies indicated the presence of Salmonella spp. and Listeria monocytogenes in one and three samples, respectively. When PCR was applied to the pre-enrichment broths, Salmonella spp. was evidenced in eight cheese samples and Listeria monocytogenes in twelve samples. The samples that tested positive using the culture methods were among the samples that tested positive using PCR.

Of the Salmonella spp.-positive samples, five were from Serra da Canastra (A11, A39, A55, A60, and A61); one was from Patos de Minas (A53); one was from Araxá (A54); and one was from Serro (A4).

Listeria monocytogenes was found in six samples from Serra da Canastra (A12, A31, A43, A76, A77, and A83), two from Serro (A14 and A87), one from Araxá (A3), one from Salitre (A13), one from Cerrado Mineiro (A16), and one from Patos de Minas (A51).

\subsection{Coagulase-Positive Enterotoxigenic Staphylococci}

The majority of the samples presented counts of coagulase-positive staphylococci below $10^{2} \mathrm{CFU} / \mathrm{g}$. In $35 \%$ of the cheese samples, the counts ranged from $1.9 \times 10^{2}$ to $6.7 \times 10^{6} \mathrm{CFU} / \mathrm{g}$. In $32 \%$ of the samples, the counts surpassed the limit of $10^{3} \mathrm{CFU} / \mathrm{g}$, which was set by the Brazilian regulation for cheeses in a retail environment [19].

All the tested coagulase-positive staphylococci isolates $(n=159)$ presented at least one enterotoxin gene. The seh and seg genes were the most prevalent, found in $88.7 \%$ and $74.8 \%$ of the tested isolates, respectively, which corresponded to $94.3 \%$ and $97.1 \%$ of the cheeses containing coagulase-positive staphylococci, respectively, and to $33 \%$ and $34 \%$ of the Minas artisanal cheeses included in this study, respectively. The genes related to classical enterotoxins (sea, seb, sec, sed, and see) were less frequent or were absent altogether: sea, seb, sec, and see were detected in $17 \%$ of the isolates, which corresponded to $14 \%$ of the studied cheeses, and none of the tested isolates presented the sed gene.

\subsection{Total Coliforms and Escherichia coli}

The range of counts of total coliforms was wide: they varied from 20 to $2.8 \times 10^{7} \mathrm{CFU} / \mathrm{g}$. In $10 \%$ of the samples, the counts of E.coli were above $10^{3} \mathrm{CFU} / \mathrm{g}$, which is the limit set by the Brazilian regulation for this type of cheese in a retail environment [19].

Most of the Minas artisanal cheese samples that tested positive for Salmonella spp. $(87.5 \%)$ also tested positive for total coliforms, E. coli, and coagulase-positive staphylococci 
(Table 2), while the majority of positive samples for L. monocytogenes were negative for total coliforms, E. coli, and staphylococci (Table 3).

Table 2. Hygiene indicators in Salmonella spp.-positive Minas artisanal cheese samples.

\begin{tabular}{cccc}
\hline $\begin{array}{c}\text { Cheese } \\
\text { Sample }\end{array}$ & Total Coliforms & $\begin{array}{l}\text { Counts (CFU/g) } \\
\text { E.coli }\end{array}$ & Coagulase-Positive Staphylococci \\
\hline A4 & $<10$ & $<10$ & $<10$ \\
A11 & $1.0 \times 10^{2}$ & $<10$ & $1.9 \times 10^{3}$ \\
A39 & $2.0 \times 10^{4}$ & $8 \times 10^{2}$ & $1.0 \times 10^{4}$ \\
A53 & $2.5 \times 10^{3}$ & $2.3 \times 10^{3}$ & $<10$ \\
A54 & $<10$ & $<10$ & $2.0 \times 10^{2}$ \\
A55 & $4.3 \times 10^{2}$ & 85 & $2.6 \times 10^{3}$ \\
A60 & $<10$ & $<10$ & $6.5 \times 10^{4}$ \\
A61 & $3.5 \times 10^{3}$ & $4.4 \times 10^{2}$ & \\
\hline
\end{tabular}

Table 3. Hygiene indicators in Listeria monocytogenes-positive Minas artisanal cheese samples.

\begin{tabular}{cccc}
\hline $\begin{array}{c}\text { Cheese } \\
\text { Sample }\end{array}$ & Total Coliforms & $\begin{array}{l}\text { Counts (CFU/g) } \\
\text { E.coli }\end{array}$ & Coagulase-Positive Staphylococci \\
\hline A3 & $1.1 \times 10^{6}$ & $<10$ & $8.8 \times 10^{4}$ \\
A12 & $<10$ & $<10$ & $<10$ \\
A13 & $<10$ & $<10$ & $<10$ \\
A14 & $<10$ & $<10$ & $<10$ \\
A16 & $<10$ & $<10$ & $<10$ \\
A31 & $<10$ & $<10$ & $<10$ \\
A43 & $<10$ & $<10$ & $<10$ \\
A51 & $3.0 \times 10^{3}$ & $<10$ & $<10$ \\
A76 & $1.1 \times 10^{2}$ & $1.1 \times 10^{2}$ & $<10$ \\
A77 & $<1$ & $<10$ & $<10$ \\
A83 & $<10$ & $<10$ & $<10$ \\
A87 & $<10$ & $<10$ & $<10$ \\
\hline
\end{tabular}

\section{Discussion}

Raw milk cheeses constitute an rich environment for a variety of contaminant microorganisms [34]. The occurrence of Salmonella spp. in artisanal cheeses is a consequence of contaminated raw milk or direct contact with infected animals and humans during processing. In retail environments, lack of hygiene is another factor that contributes to the occurrence of this pathogen in cheeses $[25,26]$. In this study, Salmonella spp. was detected in a small number of cheese samples (one, when the culture method was used, and eight, when PCR was applied). Despite being manufactured with raw milk and being exposed to opportunities for contamination during manufacturing and post-processing, the low occurrence can be explained by the diverse microbiota in these products where production of antimicrobial compounds, such as bacteriocins and organic acids, can be expected [35].

Most of the Minas artisanal cheese samples that tested positive for Salmonella spp. also tested positive for total coliforms, E. coli, and coagulase-positive staphylococci (Table 2), evidencing the relationship between hygiene failure indicators and the probability of detection of Salmonella spp. Results of this study reinforce that good manufacturing and handling practices must be adopted not only during the production of the cheese but also in retail environments where the cheese is stored, displayed, and maintained for sale.

The occurrence of L. monocytogenes in the tested samples was also low. Despite being ubiquitous, the low occurrence detected by the ISO (3\%) and PCR (12\%) methods can be attributed to the lactic acid bacteria present in the cheese samples. Lactic acid bacteria are capable of producing lactic acid and other antilisterial metabolites, such as hydrogen peroxide, diacetyl, L. reuteri, and bacteriocins, even during cold storage [36]. Total coliforms are known as important competitors for L. monocytogenes, and when present in high populations in cheeses, they can interfere with the detection of pathogens [17]. Additionally, the detection of L. monocytogenes may be affected by the presence of other 
species of Listeria, especially L. innocua, which has a faster growth rate and may negatively impact the laboratory detection of L. monocytogenes [17].

The occurrence of L. monocytogenes in cheeses is related to its ability to survive and/or multiply in these products and in the cheese-processing environment, which results in the formation of persistent biofilms [16]. When cleaning and sanitation procedures are inadequate, L. monocytogenes can colonize and persist in food processing plants for years [17]. After colonization, L. monocytogenes can easily spread through contaminated contact materials, inadequate personnel movement, and food workflows [16].

The lack of hygiene at the retail level is another factor that contributes to the occurrence of L. monocytogenes in cheeses. Handling procedures, such as cutting an entire wheel of cheese into smaller portions or slicing it for sale, present additional risks of crosscontamination by compromising the traceability as one single contaminated cheese wheel can be cut several times before reaching the consumer $[25,26]$. In this sense, the study of Oxaran et al. [17] indicated that L. monocytogenes was absent in samples of mozzarella cheese when collected directly from the producers, but the samples were positive when collected from retail stores (18.8\%) after slicing. Gaulin et al. [15] reported that pasteurized milk cheese contaminated with L. monocytogenes was the cause of a large outbreak in 2008 in Quebec, Canada. Wide cross-contamination was evidenced when the same strain was isolated from the environment of the cheese processing factory, from the environment of the retailers selling the cheese, as well as from different batches of the cheese.

The majority of the samples that tested positive for L. monocytogenes was negative for total coliforms, staphylococci, and E. coli (Table 2), which corroborates studies that indicate the strong competition between these microorganisms: when present in large quantities, the probability of detecting L. monocytogenes is lower [36].

The higher positivity outcome for Salmonella spp. and L. monocytogenes in cheeses when the pathogens were investigated using real-time PCR applied to the pre-enrichment broths versus using conventional culture methods can be explained by the greater sensitivity and specificity of the PCR method [37]. Low populations of pathogens in food in association with the sublethal injury caused by processing, in addition to competition with other bacteria, make their detection more difficult when conventional cultivation methods are employed [36].

In $32 \%$ of the samples, the counts of coagulase-positive staphylococci were above $10^{3} \mathrm{CFU} / \mathrm{g}$, i.e., these samples were in disagreement with the Brazilian federal legislation that establishes this maximum limit (M) for cheeses in retail environments [19]. All coagulase-positive staphylococci isolates were identified as Staphylococcus aureus.

The occurrence of Staphylococcus aureus in the Minas artisanal cheese samples was expected since this genus is frequently detected in bulk tank milk, and it has also been found in the skin and mucous membranes of animals and humans, the surfaces of dairy equipment, and the milking environment [8]. Artisanal cheese production, in particular, is characterized by frequent manipulation, increasing the transfer potential of Staphylococcus spp. from employees, utensils, and equipment to the final products [1]. For these reasons, Staphylococcus spp. is considered a good indicator of whether proper handling and manufacturing practices are maintained during cheese processing [25]. The favorable, intrinsic conditions encountered in the cheeses, such as $\mathrm{pH}$, water activity, and $\mathrm{NaCl}$ concentration, favor the growth of Staphylococcus spp. [9,18].

Although controversial, the capability of producing enterotoxins and coagulase has always been associated with the pathogenic potential of Staphylococcus spp. [8]. Therefore, official guidelines in Brazil and other countries consider the counts of these microorganisms as a safety benchmark $[19,20]$, where high counts indicate hygiene failures during cheese production or marketing and a possible health risk for consumers. The presence of at least one enterotoxin gene in the $S$. aureus isolates was not a surprise, as previous studies conducted with Brazilian artisanal cheeses have reported similar results $[7,18]$. However, the high prevalence of genes encoding non-classical enterotoxins, notably seg and seh, is noteworthy, suggesting a possible switch in the enterotoxigenic profile of the coagulase- 
positive staphylococci in these cheeses. Other studies have also reported that the seh gene was the most frequent in the Staphylococcus aureus isolated from Canastra cheese [14].

Brazilian federal legislation does not establish limits for total coliforms in cheeses in retail environments because coliform bacteria are not a well-defined group of bacteria, and their associations with pathogens or with the safety of cheeses were ruled out long ago. However, high counts of total coliforms may represent a major burden for producers because coliform bacteria are associated with specific quality characteristics of cheeses, such as $\mathrm{pH}[38]$.

In contrast, Escherichia coli is a human fecal commensal and representative of the intestinal environment, and it is considered a good indicator of fecal contamination [34]. Thus, detection of E. coli in Minas artisanal cheese samples indicates poor hygiene in retail environments, and its presence may represent a risk factor to consumer health [39]. E. coli was detected in $31 \%$ of the Minas artisanal cheese samples, with counts between 10 and $2.5 \times 10^{7} \mathrm{CFU} / \mathrm{g}$, and in $10 \%$ of the samples, the counts exceeded the limit established by the federal legislation for cheeses at retail locations $\left(10^{3} \mathrm{CFU} / \mathrm{g}\right)$. A large percentage $(63.3 \%)$ of samples that tested positive for total coliforms were also positive for E. coli. Trmčić et al. [38] observed that the predicted chances of finding the Escherichia species in cheeses prepared with raw milk with high counts of total coliforms were 13.9 times greater than in cheeses manufactured with pasteurized milk.

\section{Conclusions}

This study presents another snapshot of the microbiological characteristics of the most popular artisanal cheese available on the market in the city of São Paulo. The results of this study complement the recent systematic review published by Camargo et al. in 2021 [40], indicating that artisanal cheeses produced in Brazil still do not satisfactorily meet the microbiological criteria established by regulators, mainly due to the high counts of coagulase-positive Staphylococcus and total coliforms. Despite the low prevalence of Salmonella spp. and Listeria monocytogenes, the results reinforce that safety and quality management tools, such as good hygiene practices and HACCP, must be applied not only at the production level but also in retail environments in order to reduce the possible risks to consumer health, particularly for people belonging to high-risk groups, such as the elderly, pregnant people, and the immunocompromised.

Author Contributions: Conceptualization, B.D.G.d.M.F., J.R.A. and K.G.B.; methodology, J.R.A. and K.G.B.; investigation, J.R.A. and K.G.B.; writing-original draft preparation, J.R.A. and K.G.B.; writing-review and editing, B.D.G.d.M.F.; supervision, B.D.G.d.M.F.; project administration, B.D.G.d.M.F.; funding acquisition, B.D.G.d.M.F. All authors have read and agreed to the published version of the manuscript.

Funding: This research was funded by the São Paulo Research Foundation (grants 2013/07914-8, 2018/02630-5 and 2019/03176-9).

Informed Consent Statement: Not applicable.

Conflicts of Interest: The authors declare no conflict of interest.

\section{References}

1. Johnson, M.E. A 100-year review: Cheese production and quality. J. Dairy Sci. 2017, 100, 9952-9965. [CrossRef] [PubMed]

2. Guiné, R.P.F.; Correia, P.M.R.; Ferrão, A.C. Cheeses around the World: Types, Production, Properties and Cultural and Nutritional Relevance; Nova Science Publishers: New York, NY, USA, 2019; ISBN 978-1-53615-418-4.

3. Pineda, A.P.A.; Campos, G.Z.; Pimentel-Filho, N.J.; Franco, B.D.G.D.M.; Pinto, U.M. Brazilian artisanal cheeses: Diversity, microbiological safety, and challenges for the sector. Front. Microbiol. 2021, 12, 732. [CrossRef] [PubMed]

4. Kamimura, B.A.; De Filippis, F.; Sant'Ana, A.S.; Ercolini, D. Large-scale mapping of microbial diversity in artisanal Brazilian cheeses. Food Microbiol. 2019, 80, 40-49. [CrossRef] [PubMed]

5. Monteiro, R.P.; Matta, V.M. Queijo Minas Artesanal; Valorizando a Agroindustria Familiar. EMBRAPA (Empresa Brasileira de Pesquisa Agropecuária). 2018. Available online: https://ainfo.cnptia.embrapa.br/digital/bitstream/item/199625/1/LivroQueijo-Minas-Artesanal-Ainf (accessed on 27 August 2021). 
6. Araújo, J.P.A.; Camargo, A.C.; Carvalho, A.F.; Nero, L.A. Uma análise histórico-crítica sobre o desenvolvimento das normas brasileiras relacionadas a queijos artesanais. Arq. Bras. Med. Veterinária Zootec. 2020, 72, 1845-1860. [CrossRef]

7. Andretta, M.; Almeida, T.T.; Ferreira, L.R.; Carvalho, A.F.; Yamatogi, R.S.; Nero, L.A. Microbial safety status of Serro artisanal cheese produced in Brazil. J. Dairy Sci. 2019, 102, 10790-10798. [CrossRef]

8. Basanisi, M.G.; Nobili, G.; LA Bella, G.; Russo, R.; Spano, G.; Normanno, G.; La Salandra, G. Molecular characterization of Staphylococcus aureus isolated from sheep and goat cheeses in southern Italy. Small Rumin. Res. 2016, 135, 17-19. [CrossRef]

9. Borelli, B.M.; Lacerda, I.C.A.; Brandao, L.R.; Vianna, C.R.; Ferreira, M.C.; Gomes, F.C.O.; Carmo, L.S.; Heneine, L.G.D.; Rosa, C.A. Identification of Staphylococcus spp. isolated during the ripening process of a traditional Minas cheese. Arq. Bras. Med. Veterinária Zootec. 2011, 63, 481-487. [CrossRef]

10. Campagnollo, F.B.; Gonzales-Barron, U.; Cadavez, V.A.P.; Sant'Ana, A.S.; Schaffner, D.W. Quantitative risk assessment of Listeria monocytogenes in traditional Minas cheeses: The cases of artisanal semi-hard and fresh soft cheeses. Food Control. 2018, 92, 370-379. [CrossRef]

11. Castellanos-Rozo, J.; Pérez Pulido, R.; Grande, M.; Lucas, R.; Gálvez, A. Potentially pathogenic bacteria isolated from Paipa cheese and its susceptibility profiles to antibiotics and biocides. Braz. J. Microbiol. 2021, 52, 1535-1543. [CrossRef]

12. De Medeiros, N.C.; Abrantes, M.R.; De Medeiros, J.M.S.; da Silva Campêlo, M.C.; de Oliveira Rebouças, M.; Costa, M.G.A.; da Silva, J.B.A. Quality of milk used in informal artisanal production of coalho and butter cheeses. Semin. Ciências Agrárias 2017, 38, 1955-1962. [CrossRef]

13. Fagnani, R.; Nero, L.; Rosolem, C. Why knowledge is the best way to reduce the risks associated with raw milk and raw milk products. J. Dairy Res. 2021, 88, 238-243. [CrossRef]

14. Ferreira, M.A.; Bernardo, L.G.; Neves, L.S.; Campos, M.R.H.; Lamaro-Cardoso, J.; André, M.C.P. Virulence profile and genetic variability Staphylococcus aureus isolated of from artisanal cheese. J. Dairy Sci. 2016, 99, 8589-8597. [CrossRef]

15. Gaulin, C.; Ramsay, D.; Bekal, S. Widespread listeriosis outbreak attributable to pasteurized cheese, which led to extensive cross-contamination affecting cheese retailers, Quebec, Canada, 2008. J. Food Prot. 2012, 75, 71-78. [CrossRef] [PubMed]

16. Melero, B.; Stessl, B.; Manso, B.; Wagner, M.; Esteban-Carbonero, Ó.J.; Hernández, M.; Rovira, J.; Rodriguez-Lázaro, D. Listeria monocytogenes colonization in a newly established dairy processing facility. Int. J. Food Microbiol. 2019, 289, 64-71. [CrossRef] [PubMed]

17. Oxaran, V.; Lee, S.H.I.; Chaul, L.T.; Corassin, C.H.; Barancelli, G.V.; Alves, V.F.; Oliveira, C.A.F.; Gram, L.; De Martinis, E.C.P. Listeria monocytogenes incidence changes and diversity in some Brazilian dairy industries and retail products. Food Microbiol. 2017, 68, 16-23. [CrossRef] [PubMed]

18. Viana, F.R.; Oliveira, A.D.L.; Carmo, L.S.; Rosa, C.A. Occurrence of coagulase-positive Staphylococci, microbial indicators and physical-chemical characteristics of traditional semihard cheese produced in Brazil. Int. J. Dairy Technol. 2009, 62, $372-377$. [CrossRef]

19. Brasil Ministério da Saúde. Agência Nacional de Vigilância Sanitária. Instrução Normativa n ${ }^{\circ} 60$, de 23 de dezembro de 2019. Estabelece as listas de padrões microbiológicos para alimentos. Diário Oficial da União, Brasília, 26 de dezembro de 2019. Edição 249. Seção 1. Página 133. Available online: https:/ / www.in.gov.br/web/dou/-/instrucao-normativa-n-60-de-23-de-dezembro-de-20 19-235332356 (accessed on 11 August 2021).

20. EC (European Commission). Commission Regulation No 2073/2005 of 15 November 2005 on Microbiological Criteria for Foodstuffs. Off. J. Eur. Communities 2005, 1-29. Available online: http:/ / eurlex.europa.eu/LexUriServ/LexUriServ.do?uri= CONSLEG:2005R2073:20071227:EN:PDF (accessed on 11 August 2021).

21. Camargo, A.C.; Costa, E.A.; Fusieger, A.; de Freitas, R.; Nero, L.A.; De Carvalho, A.F. Microbial shifts through the ripening of the "Entre Serras" Minas artisanal cheese monitored by high-throughput sequencing. Int. Food Res. J. 2021, 139, 109803. [CrossRef] [PubMed]

22. Kamimura, B.A.; Cabral, L.; Noronha, M.F.; Baptista, R.C.; Nascimento, H.M.; Sant'Ana, A.S. Amplicon sequencing reveals the bacterial diversity in milk, dairy premises and Serra da Canastra artisanal cheeses produced by three different farms. Food Microbiol. 2020, 89, 103453. [CrossRef]

23. Kamimura, B.A.; Magnani, M.; Luciano, W.A.; Campagnollo, F.B.; Pimentel, T.C.; Alvarenga, V.O.; Pelegrino, B.O.; Cruz, A.G.; Sant'Ana, A.S. Brazilian artisanal cheeses: An overview of their characteristics, main types and regulatory aspects. Compr. Rev. Food Sci. Food Saf. 2019, 18, 1636-1657. [CrossRef]

24. Sant'Anna, F.M.; Wetzels, S.U.; Cicco, S.H.S.; Figueiredo, R.C.; Sales, G.A.; Figueiredo, N.C.; Nunes, C.A.; Schmitz-Esser, S.; Mann, E.; Wagner, M.; et al. Microbial shifts in Minas artisanal cheeses from the Serra do Salitre region of Minas Gerais, Brazil throughout ripening time. Food Microbiol. 2019, 82, 349-362. [CrossRef]

25. Lahou, E.; Uyttendaele, K. Growth potential of Listeria monocytogenes in soft, semi-soft and semi-hard artisanal cheeses after post-processing contamination in deli retail establishments. Food Control 2017, 76, 13-23. [CrossRef]

26. Sauders, B.D.; D'amico, D.J. Listeria monocytogenes cross-contamination of cheese: Risk throughout the food supply chain. Epidemiol. Infect. 2016, 144, 2693-2697. [CrossRef] [PubMed]

27. BrasilMinistério da Agricultura, Pecuária e Abastecimento. Secretaria de Defesa Agropecuária (DISPOA). Instrução Normativa $n^{\circ}$ 62, de 26 de agosto de 2003. Oficializa os Métodos Analíticos Oficiais para Análises Microbiológicas para Controle de Produtos de Origem Animal e Água. Diário Oficial da União, Brasilia, 26 de agosto de 2003. Seção 1. Available online: https:/ /www.defesa. agricultura.sp.gov.br/legislacoes/instrucao-normativa-sda-62-de-26-08-2003,665.html (accessed on 10 August 2021). 
28. ISO (International Organization for Standardization). Microbiology of the Food Chain-Horizontal Method for the Detection, Enumeration and Serotyping of Salmonella —Part 1: Detection of Salmonella spp, 1st ed.; The International Organization for Standardization: London, UK, 2017. Available online: https:/ / www.iso.org (accessed on 10 August 2021).

29. ISO (International Organization for Standardization). Microbiological Examination of the Food Chain-Horizontal Method for Detection and Enumeration of Listeria monocytogenes and of Listeria spp.-Part 1: Detection Method; The International Organization for Standardization: London, UK, 2017. Available online: https://www.iso.org (accessed on 10 August 2021).

30. Bennett, R.W.; Lancette, G.A. Staphylococcus aureus. In Bacteriological Analytical Manual Online; Food and Drug Administratrion (FDA), 8th ed.; FDA: Silver Spring, MD, USA, 2001. Available online: https://www.fda.gov/food/laboratory-methods-food/ bam-chapter-12-staphylococcus-aureus (accessed on 10 August 2021).

31. Gholamzad, M.; Khatami, M.R.; Ghassemi, S.; Vaise Malekshahi, Z.; Shooshtari, M.B. Detection of Staphylococcus Enterotoxin B (SEB) Using an Immunochromatographic Test Strip. Jundishapur J. Microbiol. 2015, 8, e26793. [CrossRef] [PubMed]

32. Monday, S.R.; Bohach, G.A. Use of Multiplex PCR To Detect Classical and Newly Described Pyrogenic Toxin Genes in Staphylococcal Isolates. J. Clin. Microbiol. 1999, 37, 3411-3414. [CrossRef]

33. Jarraud, S.; Mougel, C.; Thioulouse, J.; Lina, G.; Meugnier, H.; Forey, F.; Nesme, X.; Etienne, J.; Vandenesch, F. Relationships between Staphylococcus aureus genetic background, virulence factors, agr groups (alleles), and human disease. Infect. Immun. 2002, 70, 631-641. [CrossRef]

34. Metz, M.; Sheehan, J.; Feng, P.C. Use of indicator bacteria for monitoring sanitary quality of raw milk cheeses-A literature review. Food Microbiol. 2020, 85, 103283. [CrossRef]

35. Dores, M.T.D.; Nobrega, J.E.D.; Ferreira, C.L.D.L.F. Room temperature aging to guarantee microbiological safety of Brazilian artisan Canastra cheese. J. Food Sci. Technol. 2013, 33, 180-185. [CrossRef]

36. Aragon-Alegro, L.C.; Lima, E.M.F.; Palcich, G.; Nunes, T.P.; de Souza, K.L.O.; Martins, C.G.; Noda, P.K.; Destro, M.T.; Pinto, U.M. Listeria monocytogenes inhibition by lactic acid bacteria and coliforms in Brazilian fresh white cheese. Braz. J. Microbiol. 2021, 52, 847-858. [CrossRef]

37. Ripolles-Avila, C.; Martínez-Garcia, M.; Capellas, M.; Yuste, J.; Fung, D.Y.; Rodríguez-Jerez, J.J. From hazard analysis to risk control using rapid methods in microbiology: A practical approach for the food industry. Compr. Rev. Food Sci. 2020, 19, 1877-1907. [CrossRef]

38. Trmčić, A.; Chauhan, K.; Kent, D.J.; Ralyea, R.D.; Martin, N.H.; Boor, K.J.; Wiedmann, M. Coliform detection in cheese is associated with specific cheese characteristics, but no association was found with pathogen detection. J. Dairy Sci. 2016, 99, 6105-6120. [CrossRef]

39. Finger, J.A.; Baroni, W.S.; Maffei, D.F.; Bastos, D.H.; Pinto, U.M. Overview of foodborne disease outbreaks in Brazil from 2000 to 2018. Foods 2019, 8, 434. [CrossRef] [PubMed]

40. Camargo, A.C.; de Araújo, J.P.A.; Fusieger, A.; de Carvalho, A.F.; Nero, L.A. Microbiological quality and safety of Brazilian artisanal cheeses. Braz. J. Microbiol. 2021, 52, 393-409. [CrossRef] [PubMed] 